\title{
Fishermen And Fish Farmers Household Economy Around Coal Mining Of Tanah Laut Regency, South Kalimantan, Indonesia
}

\author{
Achmad Syamsu Hidayat ${ }^{1}$, Marsoedi ${ }^{2}$, Nuddin Harahab ${ }^{2}$, Luthfi Fatah ${ }^{3}$ \\ ${ }^{I}$ Agricultural Sciences, Brawijaya University, Malang, \\ ${ }^{2}$ Faculty of Fisheries and Marine Science, Brawijaya University, \\ ${ }^{3}$ Faculty of Agriculture, Lambung Mangkurat University, Banjarmasin
}

\begin{abstract}
This study was aimed at analyzing the fishermen and the fish farmers household economic conditions living around the coal mining activity site and comparing them to those living in the site of no coal mining activity. Tanah Laut Regency has many fishermen and fish farmers and there are also coal mining activities. The study found that the mining companies operating on the study site was small-scaled companies, but that operating around the villages was large-scaled one. This mining operations contribute to the carrying capacity of environmental conditions, especially fish farming activities. Shrimp pond activities in the study area have always failed in the last several years that caused the fishermen and the fish farmers have to move to other work in order to meet their household economic needs and even there were some fish ponds sold.The small-scaled coal mining companies in this area have not conducted the empowerment program for surrounding communties despite providing some non-skill working opportunies for few local people, such as security staff and other loading and unlouding labors.Small-scaled fishermen (<5GT) of Muara Kintap village, particularly danish seine bottom fish and shrimp danish seine fishermen, were not directly affected by the mining activities, because their fishing grounds were in the lane of 3-6 miles, but for traditional smale-scaled fishermen with the fishing ground less than 3 miles, it is potential to have conflict in utilizing the coastal areas. In general, average monthly income of small-scaled fishermen in Muara Kintap was higher than those in Bawah Layung, Kurau District. Thirteen percent of the fishermen have monthly incomebelow the labor minimum wage of South Kalimantan, and all belonged to traditional small-scaled fishermen having limited access to the aquatic resources.
\end{abstract}

Keywords:Fishermen, fish farmer, coal mining, househoud economy

\section{Introduction}

Tanah Laut Regency is astronomically located at the position between $3^{\circ} 30^{\prime} 33^{\prime \prime}-4^{\circ} 11^{\prime} 38^{\prime \prime}$ SL and between $114^{\circ} 30^{\prime} 20^{\prime \prime}-15^{\circ} 23^{\prime} 31^{\prime \prime}$ EL with an area of $3,846.86 \mathrm{~km}^{2}$. This regency has a coastal line of 175.93 kmlong covering 6 districts, i.e. Bumi Makmur, Kurau, Takisung, Panyipatan, Jorong and Kintap. Based on Indonesia Law Numbered 27, 2007, the zonation planning area includes the administrative boundary of coastal districts and marine area of 4 sea miles, so that the coastal region of Tanah Laut Regency reaches 2,430.16 $\mathrm{km}^{2}$ or about $63.15 \%$ of the total breadth.

The coastal area of Tanah Laut Regency possesses not only high fisheries resources potential, but it is rich in mine and mineral resources (coal distributed in an area of 314.4 million $\mathrm{m}^{2}$ ). The fisheries resources have been employed by the communities in various productive businesses, such as shrimp farming pond and fishing as their major livelihood source.The use of mine and mineral resources has also developed fast since early 1990sand increased after the regional autonomy laws, 2004, had been issued. Based on 2012 data of Regional Development Planning Board of South Kalimantan Province, there are 53 legal mining companies in the coastal area of Tanah Laut Regency and Coal Mining Agreement on the area of about 58,960 ha (Regional Development Planning Board of Tanah Laut Regency, 2013).

The mining industry activities have given positive benefit on the macro-economic growth of the regency, particularly regional revenue (Gross Regional Domestic Revenue is 4.4\% for mining sector in 1999 rose to $9.52 \%$ in 2006 and $10.90 \%$ in 2012), but these also resulted in potential negative impacts toward coastal environmental quality degradations, especially fishermen and fish farmers, who use the coastal area to make their major livelihood.

This study was aimed at analyzing the economic conditions of the fishermen's and shrimp farmers' households around the area of coal mining activitiesand comparing them with those around the area of no coal mining activities. 


\section{Method}

The study was carried out by surveys using a comparatively descriptive method. Survey locations were set on purpose in Muara Kintap village, Kintap district, Tanah Laut regency, South Kalimantan province, since it highly represented the studied problems. As fisheries activity condition comparison, Bawah Layung village, Kurau district, Tanah Laut regency, was selected, in which it was a coastal area with no coal mining activities.

Samples were fisheries households grouped as fishermen and shrimp farmers.For the former, samples were small-scaled fishermen using less than 5 GT-powered motor boats. Number of samples was determined using the formula of Slovin(Uma Sakaran, 2000).

The fishermen's and shrimp farmers' household economy was approached using descriptive analysis on their fisheries activities and income, multiple living patterns of the fisheries households, and fisheries activity patterns run by the fisheries households on daily or yearly basis.

\section{Coal Mining Activities}

\section{Results And Discussion}

Coal mining companies whose activities are in the area of Muara Kintap are small-scaled mining companies,PT. Surya Sakti Darma Kencana (SSDK),using Kintap River andPT. Pribumi Citra Mega Utama (PCMU)using the coastal area.

Various stockpile and harbor activities of PT. SSDK were initially protested by the communities of Muara Kintap, particularly the fish farmers around the area. The stockpile and harbor activities have bad impact on the fish farming activities due to increased atmospheric dust content from these activities. Nevertheless, the companies denied the fact since they have tried to prevent the impact through routine watering in the potentially dusty areas, the use of dust vacuumer, and surrounding land acquirement.

Other complaints are the impacts of coal transportation activities of PT. SSDK and other companies, such as fish pond dike damages around the edge of Kintap River and high water turbidity from waves generated by the operations of barges and tugboats transporting coal back and forth along the river every day. Whether the facts are true or not, the present study found numerous damaged and disfunctioned fishpond dikes.

The operation of barges through this river also passes the Fish Landing Base of Muara Kintap which is the fishermen's boat launching site. These activities certainly give physical impacts, particularly dense sailing lane in the estuary of Kintap River. The sailing route of the coal barges in the rivermouth and along the river to the coal harbor is managed by PT. Mitra Falak Lestari. The barges used were 270 feetlong with a total capacity of 6,000 MT, butmost of them loaded only 5,000 - 5,200 MT of coal since the barge draft was only 4.2 meter high in accordance with the depth condition of Kintap River.

The coal harbor operation of PT.Pribumi Citra Mega Utama whose position is on the beach facing the ocean is not related at all with Kintap River. However, high number of coal-carrying barges at anchor waiting queue for unloading coal at the dedicated port at least limitsthe traditional small-scaled fishermen's fishing operations in 3-mile zone or laneIA.

The conflict interest for areal utilization between fishing boats and coal-carrying barges has not resulted in any problem. It could result from the awareness that coastal waters is a common property and opened access. The presence of Fish Landing Base withmany other facilities, such as berthing site, dock, workshop, production inputs (fuel, ice, food) and catch marketing around Muara Kintap is familiar with incoming fishing vessels from outside the area ("andon") in certain seasons.

Based on the survey, the coal mining companies at the study site did not implement the community empowerment program for surrounding communities as mandated by the Indonesian Laws numbered 4, 2009. They just provide some assistance for particular cases, such as fire disaster.The working opportunity for surrounding communities in the small-scaled mining companies is available only for security staff, stockpile checker, and barge hawser rope fastener (loading and unloading labor). Some fishermen who have 7 GT boats could also work as direction control of barge rear when anchoring toward the estuary.

The large-scaled coal mining company operating outside the study site is PT. ArutminIndonesia, and all mining activities are not done in Muara Kintap. In spite of that, Muara Kintap still belongs to the area of community empowerment program of PT. Arutmin Indonesia located in the ring 2 zone.

PT. Arutmin Indonesia,through itsCommunity Empowerment Resource Development (CERD), has implemented the empowerment program of surrounding communities, including Muara Kintap. This program has developed since 1998 in this village, even though it is in the form of building various public facility supports, such as public toilet, concrete road, water spring, village office, village bridge, andvillage footbridge.This program has actually met the empowerment requirements in all fields, such as education and local community economic activities, but it is just focused in the nearest area of mining actvities (ring 1 zone). 


\section{Small-scaled Fishermen's Household Economy}

Small-scaled fishermen of Muara Kintap do fishing trip every day.They who use shrimp fish bottom danish seinefished in zone IB-IIA, 3-6 miles from the beach. The traditional small-scaled fishermen used set gill net, push net, beach seine and hand line in zone IA, $<3$ miles. The former has about 20 to 25 trips per month, while the later has about 20 to 30 trips per month.

The fishing operational cost is mostly used for gas, $70-73 \%$,for the former and $51 \%$ for the latter.Their gain ranged from IDR 866,875,- to IDR 5,216,167, with an average of IDR 2,587,074,- per month. The fishing gear type-based gain is entirely presented in Fig. 1.

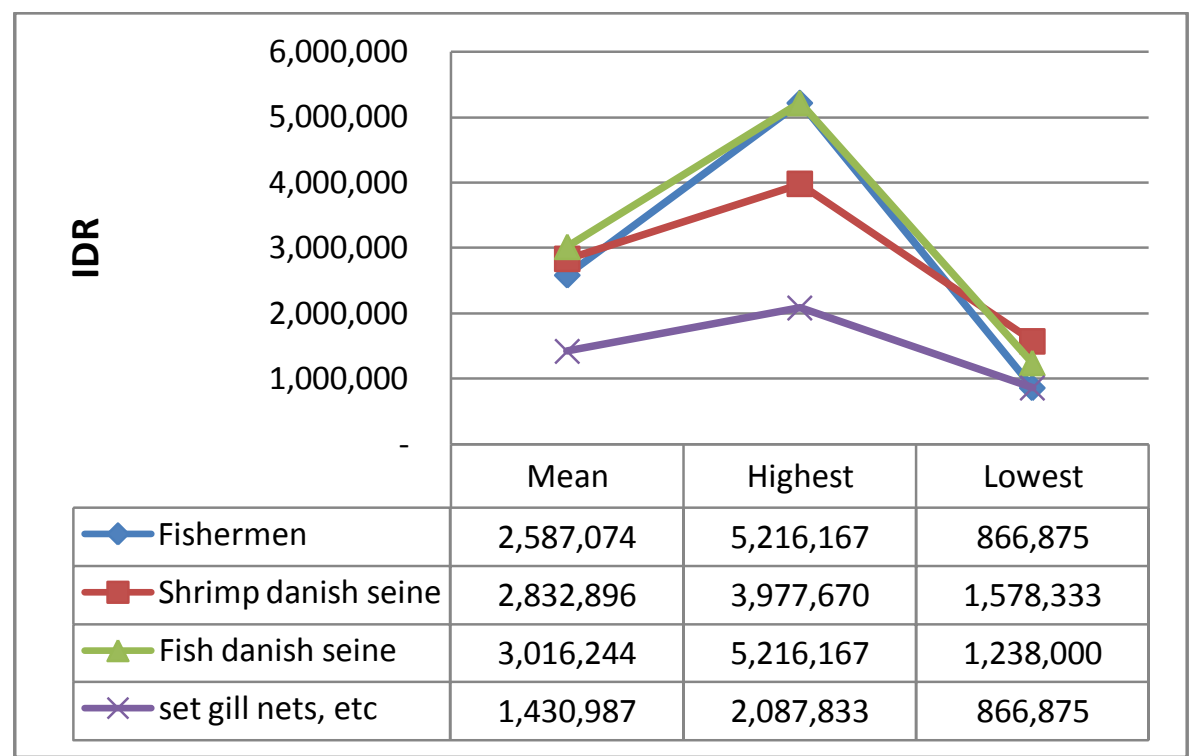

Figure1.Fishermen's average, maximum and minimum monthly gain from fishing inMuara Kintap.

Refering to the 2013 provincial minimum wage of South Kalimantan as much as 1,337,500,there are still about $13 \%$ of the fishermen whose gain is below the minimum wage(Fig.2), and all belong to traditional smallscaled fishermen with limited access to the fisheries resources due to their fishing ground in zone IA ( $<3$ miles). Furthermore, Bawah Layung fishermen, Kurau District, had average monthly gain from fishing as much asIDR 2,046,200 with the highest of IDR 3,807,100,- and the lowest of IDR 768,400,-. Compared with the 2013 minimum wage of South Kalimantan, there were $23.1 \%$ of them whose gain was below the minimum wage (Fig. $3)$.

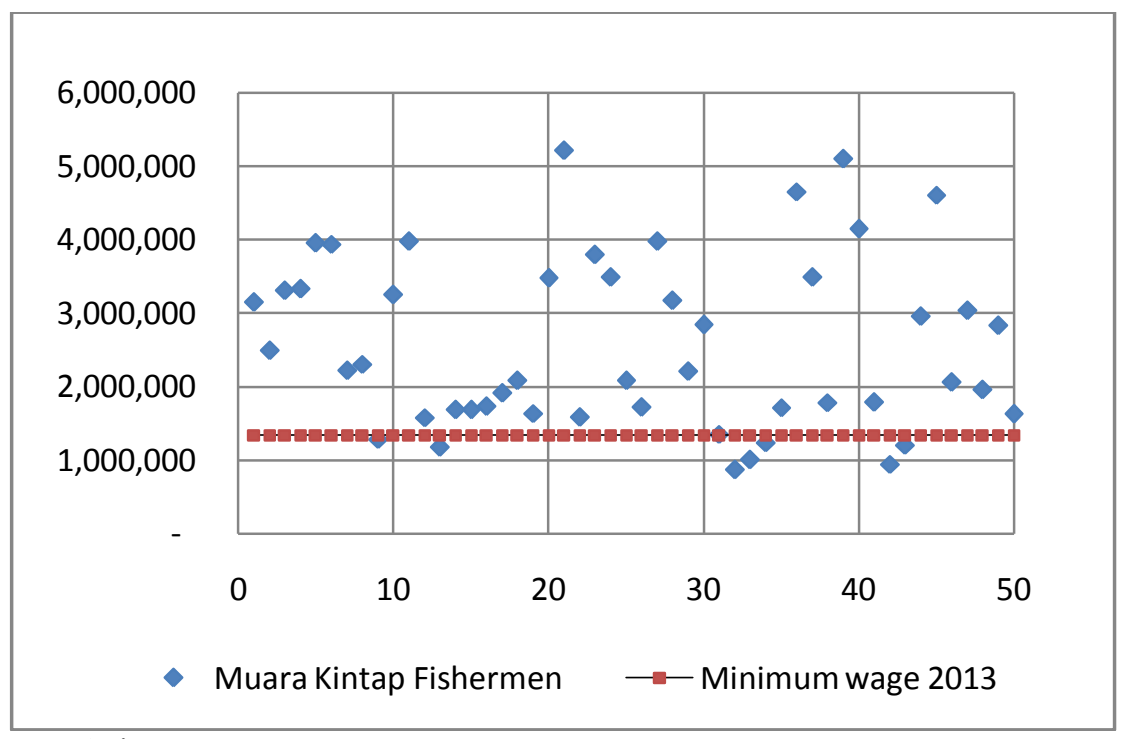

Figure 2.Fishermen's income (IDR) distribution(fishing) of Muara Kintap with South Kalimantan minimum wage of 2013. 


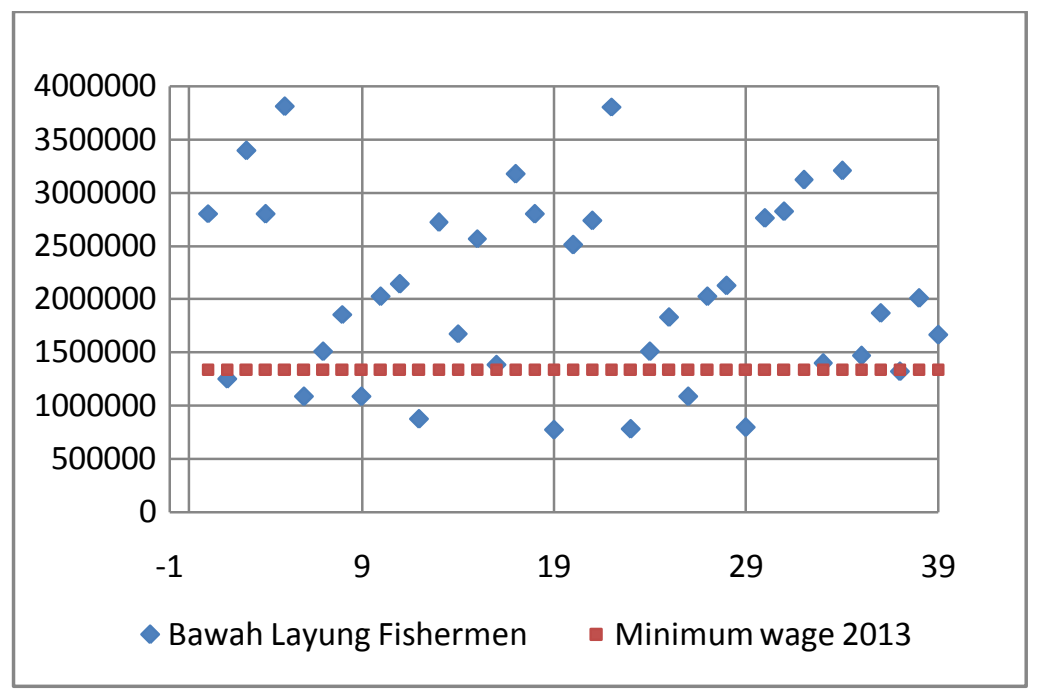

Figure3. Fishermen's income (IDR) distribution(fishing) of Bawah Layung village with South Kalimantan minimum wage of 2013

Difference test of two mean income value (t-test) showed that average monthly income of Muara Kintap small-scaled fishermen is higher (significantly different, $\mathrm{p}<0.01$ ) than that of Bawah Layung smallscaled fishermen, Kurau district, but that of the traditional small-scaled fishermen of Muara Kintap is lower (significantly different, $\mathrm{p}<0.0001$ ) than that of Bawah Layung traditional small-scaled fishermen, Kurau district.

Small-scaled fishermen ofMuara Kintap cover $16.7 \%$ of the households doing multiple livelihood pattern by running other jobs, such as shop, doing rubber plantation or as artisan.Sixty-seven percents of these are carried out by the traditional small-scaled fishermen whose income is lower than those living from fish and shrimp danish seine fishing(Table1).

Table 1.Type and monthly incomeof side job of fishermen in Muara Kintap.

\begin{tabular}{clcc}
\hline No. & \multicolumn{1}{c}{ Type of job } & Percent & income (IDR/mo.) \\
\hline 1 & Shop & 45 & $1,000,000-3,000,000,-$ \\
2 & Artisan (mason) & 11 & $\pm 2,000,000,-$ \\
3 & Timber worker & 11 & $500,000-750,000,-$ \\
4 & Rubber plantation & 33 & No production yet \\
\hline
\end{tabular}

Source: Primary dataof 2014.

Quite different condition was observed in the households of Bawah Layung fishermen, in which $90 \%$ of them did multiple livelihood patterns by doing agriculture and plantation, such as rice field and crop plantation. These activities are, of course, potentially conducted since the surrounding conditions highly support them.Rice field farming is done once a year for 4 to 6 months, from December/January to April/May. The crop plantation (chilli, tomatto) and water melon plantation activities are performed for about 2 to 3 months between April, May and June(Table 2).

Table 2. Type and income (per season)of side work of Bawah Layung fishermen.

\begin{tabular}{clcc}
\hline No & Type of work & Percent & Income (IDR/season) \\
\hline 1 & Rice field farmer & 86 & $2,100,000-8,200,000,-$ \\
2 & Farm labor & 6 & average: $5,747,900,-$ \\
3 & Crop garden & 5 & \\
4 & Water melon garden & 5 & \\
\hline
\end{tabular}

Source: Primary data of 2014.

The shrimp and fish bottom danish seinecould be operated almost along the year using their fishing vessels and changing only the fishing gear in relation with season.In west season(October/November to April/May),they operate the 1.5"-2.5" mesh-sized fish bottom danish seine, while in east wind season (May/Juneto October/November), they use 1"-1.5" mesh-sized shrimp bottom danish seine.They leave for fishing everyday around 05.00 a.m. Mid Indonesian Time and come back between 13.00 to 16.00 p.m. Each fishing trip had two net settings and haulings traditionaly called "kalung". The fishing operations do not nearly 
cause conflicts with harboring and coal transportation activities so far the fishing activities are done in the legally established locations, zone IB-IIA (3-6 miles).

\section{Fish Farmer's Household Economy}

Shrimp culture ponds inMuara Kintap, Tanah Laut regency, are not recently run by the owners. It could result from that total mortality could occur after several weeks of stocking so that the shrimp farmers are afraid of restocking the shrimp seed in their ponds. This failure occurred in the last few years making them run out of capital to do the shrimp pond culture.

This failure has occurred in all areas of Tanah Laut regency. Decline in shrimp culture activities could be indicated from no operation of shrimp farming trading companiesin this regency, either inter-island or export.In 2000, there were 14 fisheries companies actvely doing export and inter-island tradings, decreasing to 5 companies in 2007 (Fisheries and Marine Service of Tanah Laut Regency, 2008)and 4 companies in 2010(Fisheries and Marine Service of Tanah Laut Regency, 2013).

Interviews with several community figures showed that since 2007 the shrimp pond culture in this area has been unproductive because of high mortality rate from disease infection.It is in agreement with the shrimp farmer interviews that in the last few years they stopped restocking the shrimp seed due to high failure.

It is indicated that Tanah Laut regency with 1,661.10 tons of pond fisheries production in a stocking area of $1,940.30$ ha possessed a productivitiy of $856.10 \mathrm{~kg} / \mathrm{ha} /$ year in 2007 . Nevertheless, it drastically decreased in 2011 to 199.22 tons from a total stocking area of $1,759.36$ ha with a productivity of 113.24 $\mathrm{kg} / \mathrm{ha} /$ year.

The termination of this shrimp culture activity was also physically seen from the uncared pond condition, damaged dikes and control water gate, and damaged control houses.The road access to the ponds was also mostly damaged so that it was difficult to reach the houses in the culture area.Dike damages highly occurred along the left and right sides of Kintap River, and even some parts of the area have become berthing siteof coal barges and tugboatslining up in the coal harbor.Small number of ponds was still run by culturing fish and shrimps trapped in high tide for daily consumption.

The previous study in 2007 entitled "A Study on Former Stock Pile and Special Port Coal in Coastal Area" concluded that the coastal degradation of Tanah Laut Regency tended to result from terrestrial ecosystem degradation (erotion and pollution) toward the coastal area as a result of water catchment area destruction that brought about increased water mass degradation toward the downstream and dillution of coastal water salinity from river water input increment.Habitat and mangrove ecosystem degradations from salinity dillution and land conversion have caused the coastal area lose the natural sediment trapping system that eventually resulted in loss of land forming capacity seawards by sedimentation(Fisheries and Marine Service of Tanah Laut Regency, 2007).

This fact was supported by the survey and analytical data of RZWP-3-K working team of Tanah Laut Regency for 2013that major limiting factor for pond culture development in this regency was sufficiently low salinity. It could result from the occurrence of numerous rivers in this area causing low salinity concentration, particularly in rainy season and the pollution from palm plantation on the higher land, mining, harbor, and residential area potentially resulting in water pollution.Low topography of pond position was also another influencial factor, especially for Kintap district, in which high rainfalls and high tide could also flood the area(Regional Development Planning Board of Tanah Laut Regency, 2013).

Since pond culture could not give some income to the shrimp farmers of Muara Kintap makes them have to search for other livelihoods, such as crab collection, fishing gear maker, artisan, and fish seller, to financially support their families. Even some pond areas in Muara Kintap directly bordering with palmplantation area of PT. Kintap Jaya Watindo (PT. KJW) were sold by the owner as much as IDR 20,000,000 per ha.Similar condition also occurred for pond area around the coal harbor of PT. SSDK.

The fish farmers near the coal harbor mostly work as coal mining physical labors carried out by placing coal into a sack under a salary of IDR 3,000,- per sack. From this work, they could collect income of IDR 150,000 to IDR 300,000 ,- per day. However, it could not be done everyday because this work spends very high energy.Also, working as physical mining labor could only be done up to 2013 and they have to stop working since it is considered as illegal activities.

Other alternative work for people around the coal company are security staff, harbor checker, andbarge hawser rope fastener. From these jobs, people could collect money between IDR 2,000,000,- to IDR 3,000,000,per month, but not many of them could be involved.

Other job is coal fully-contained barge rear controller outgoing from the coal harbor toMuara Kintap. This job is provided to those having 7 GT boats through $4-5$ labor involvement and they could get IDR $1,500,000,-$ per trip.

Our findings reflect that number of local people working in this mining company is in agreement with the previous study that the presence of coal mining company does not significantly positively influence the 
working opportunity for local communities and does not promote economic structural development around the mining area as well (Siska, 2013). Even if there is working opportunity opened to the local communities, they have educational and skill constraints (Ilmi Hidayat, 2010) andvery low possibility to be accepted in the mining field (Harini and Apriyanto, 2011). Low educational level of the fishermen and fish farmers in the study site reflects common educational conditions of Indonesian coastal villagers in general. In line with Muflikhati (2010), fishermen's prosperity level could be indicated by very low education. In addition. Prihandoko et al . (2012) more strictly stated that fishermen in the North Coast of West Java averagely enrolled formal education for about 5 years or the fifth year of Basic School.

Based on the study of Kitula (2006), the presence of large-scaled mining company in Gieta District, Tanzania,gave benefits for surrounding communities, such as working opportunity of $42 \%$, road, water facility, and school development of $20.3 \%$, food supply of $10.8 \%$, and small business of $8.1 \%$. Even $33.8 \%$ could work in mining field.

\section{Conclusion}

1. The coal mining companies in the territory of Muara Kintap are those of small-scaled ones whose contribution to the development of fishermen's household economy is still low since olny few local people could be accepted as employees and provided business opportunity.The companydid not also implement an organized and planned empowerment program for surronding communities, and only provided some village fee and disaster like-incidental help.

2. Small scaled-fishermen of Muara Kintap, particularly fish and shrimp bottom danish seine net were not affected by coal mining activities in the study site because their fishing ground is in 3-6 milesdistance, and the fishermen use more than one type of fishing gear to be able to fish almost along the year. Their monthly mean income is higher than the 2013 minimum wage of South Kalimantanandthat of Bawah Layung fishermen, Kurau district, except that low income of the traditional small-scaled fishermen is due to limited access to the fisheries resources.

3. The fish farmers of Muara Kintap could not run the fish pond activities since the environmental carrying capacity has highly degraded, so that they have to find any other job to financially support their families. Low education level and skill have caused them difficult to have other better job.

\section{Recommendations}

1. Access development to the resources is one of the the best programs to increase the prosperity and the economy of Muara Kintap traditional small-scaled fishermen's households, since changing fishing activity to other jobs is difficult to do due to their low human resources quality.

2. Serious regional government planning programs should be made by involving all stakeholders to formulate the alternative program in prevention of economic problem of shrimp farmer's households in Muara Kintap.

\section{References}

[1]. Arifin, F. andA.S. Hidayat, 2003. Identification andecological degradation study of living resources in the coastal waters of Tanah Laut Regency. Marine and Fisheries Services, Tanah Laut Regency.

[2]. BPS-Statistics of Tanah Laut Regency, 1999. Gross Regional Domestic Product of Tanah Laut Regency South Kalimantan in1999.

[3]. BPS-Statistics of Tanah Laut Regency, 2006. Gross Regional Domestic Product of Tanah Laut Regency South Kalimantan in2006.

[4]. BPS-Statistics of Tanah Laut Regency, 2012. Gross Regional Domestic Product of Tanah Laut Regency South Kalimantan in2012.

[5]. BPS-Statistics of Indonesia, 2013, The development ofminimum wage/ProvincesinIndonesia. www.bps.go.id

[6]. Clark, R. J. 1996. Coastal Zone Management Hand Book.CRC Lewis Publishers. Boca Raton, Florida. Pp. 694

[7]. Regional Development Planning Board of Tanah Laut Regency, 2013, Data Book and Analysis of Coastal Area Zone Plan And Small Islands of Tanah Laut Regency of 2013.

[8]. Fisheries and Marine Service of Tanah Laut Regency, 2007.A Study on Former Stock Pile and Special Port Coal in Coastal Area .

[9]. Fisheries and Marine Service of Tanah Laut Regency, 2008. Yearly report of Fisheries and Marine Services of Tanah Laut Regency.

[10]. Fisheries and Marine Service of Tanah Laut Regency, 2013. Yearly report of Fisheries and Marine Services of Tanah Laut Regency..

[11]. Harini, R. andD. Apriyanto,2011. Impact of coal mining activity on the socio-economic condition of Ipuh Darat communities, Tenggarong Kutai Kartanegara. J. Bumi Indonesia. 1 (3):

[12]. http://lib.geo.ugm.ac.id/ojs/index.php/jbi/article/view/96

[13]. Kitula., A.G.N. 2006. The environmental and socio-economic impacts of mining on local livelihoods in Tanzania: A case study of Geita District.

[14]. Ilmi Hidayat, M. 2010. Impact of coal mining on the community socio-economic condition in Sei Pinang district, Banjar Regency. ZIRAA'AH, 27 (1):80-88.

[15]. Muflikhati, 2010. Kondisi Sosial Ekonomi dan Tingkat Kesejahteraan Keluarga : Kasus di Wilayah Pesisir Jawa Barat. Jurnal Ilm. Kel. \& Kons. Januari 2010; p : 1-10. ISSN:1907-6037

[16]. Muhammad, S. and Soemarno. 2005. Natural resources and coastal and marine environment of east Java. Materi Kuliah. PSLPL. Universitas Brawijaya. pp. 60

[17]. Official Situs of Tanah Laut Regency Government, 2012. Mining Potency of Tanah Laut Regency.

[18]. http://www.tanahlautkab.go.id/index.php/potensi/potensipertambangan

[19]. Prihandoko S., Amri J., Darwis S.G., I. Gusti P.P., L. Adrianto, I. Tjitradjaya, 2012. Social economic condition of the artisanal fishermen in the north coast of west Java province. J. counselling. Vol.3 No.1. ISSN 1858-2664. 
Fishermen And Fish Farmers Household Economy Around Coal Mining Of Tanah Laut Regency,

[20]. Siska,2013. Coal Industrial impact on the community social economy around Jembayan village, Loa Kulu district, Kutai Kartanegara regency, eJournal Administrasi Negara, 1 (2):473-493

[21]. Sekaran, U. Research Methods for Business: A Skill-building Approach. 3rd ed. USA: John Willey \& Sons, Inc.; 2000.

[22]. Undang-Undang Nomor 27 Tahun 2007 tentang Pengelolaan Wilayah Pesisir dan Pulau Pulau Kecil, Pemerintah Republik Indonesia. http://www.dkp.go.id/upload/UU_27_2007_\%20wilayah_Pesisir_ppk.pdf

[23]. Yunandar, 2007. Areal utilization analysis in the coastal fisheries development area of Muara Kintap, Tanah Laut Regency, South Kalimantan Province. Postgraduate Program, Doponegoro University. Semarang. 